\begin{tabular}{|llc||}
\hline \multicolumn{2}{|l|}{ Egyptian Journal of Social Work (EJSW) } & http://ejsw.journals.ekb.eg \\
Print ISSN: 2356-9204 & Online ISSN: 2356-9212 & Vol 8, Issue 1, June 2019 \\
\hline \hline
\end{tabular}

\title{
The Effectiveness of the Life Model of Social Work in Developing Life Skills for Orphans
}

\section{Hamdy Abdallah Abdelaal Abdallah (Ph.D.)}

Associate Professor-Social Work Fields Department High Institute of Social Work, Qena 


\section{The Effectiveness of the Life Model of Social Work in Developing Life Skills for Orphans}

Hamdy Abdallah Abdelaal Abdallah (Ph.D.)

Associate Professor-Social Work Fields Department

High Institute of Social Work, Qena

\section{Abstract}

This article aims to determine the feasibility of a life model of social work for the developing of life skills for orphans. The sample includes 30 orphans from the Ahmed Jabra Foundation for Boys Welfare in Qena who were randomly assigned. The sample was divided into an experimental group and a control group (15 orphans in each group). Each group was asked to complete a life skills scale for orphans (pre-test). Orphans in the experimental group were then introduced to the life model to build their life skills. The intervention lasted for 12 weeks, after which orphans in both the experimental group and the control group completed the measures again (post-test). The results suggested that using a life model in social work is an effective method of improving life skills for orphans.

Key words: orphans; life skills; social work; life model.

\section{Introduction}

An orphan is a child under 18 years of age who has lost one or both parents to any cause of death (UNICEF, 2001). A child who has lost both parents feels the need for someone who can protect and nurture him like a parent, taking care of all of his needs emotionally and financially. This will avert any feelings of isolation and loneliness for the child, and allow him to grow into a confident adult with little thought of jealousy or suspicion of others within his community (AlQazzaz, 2005, p. 159).

When a family collapses because of the death of a parent, or through divorce, the psychological and emotional health of orphaned children is affected, and they suffer from a reluctance to socialize with others (Jalal, 2013, p. 215). Hapeep's study (1995) pointed to the social problems faced by the children of residential institutions, where, it turned out, there are many social problems such as the lack of participation and interaction with others and the inability to form positive social relations resulting in withdrawal from social life and weak affiliation to the institution. Khalile's study (1995) also found that orphans placed in residential institutions suffer from feelings of isolation, introversion, anxiety, aggression, shyness, have a 
pessimistic outlook on life and poor social relations. Abo-Elfotouh's study (2004) found that there are social needs for orphans: the need for social appreciation, the need to form social relationships, the need to participate in social life. While Johnson and Grose (1994) report on the institutional care of orphans deprived of their families in Romania, where children in social welfare institutions suffer from problems such as poor academic achievement, aggressive behavior, introversion and theft. The results of the study indicate that the professional efforts made with these children to increase their consensus within institutions contribute to reducing these problems.

The attention has turned to providing life skills for orphaned children, which contribute to alleviating many of the problems they face (Elsaid, 2014). Life skills are 'abilities for adaptive behaviour that enable orphans to deal effectively with the demands and challenges of everyday life' (WHO, 2001, p.1). They can be divided into three broad categories of skills: cognitive skills for analyzing and using information, personal skills for developing personal interests and managing oneself, and inter-personal skills for communicating and interacting effectively with others (UNICEF, 2003). It is also a set of functions that help orphans successfully interact with daily life situations, provide them with the necessary scientific knowledge in areas related to life skills, and control the problems they face in their lives, community and environment (Ibrahim, 2006, p. 46).

However, the lack of life skills among orphans is one of the most important problems for which quick solutions must be sought. The outputs of social institutions lack the skills of life, and thus many fail in their careers and personal endeavours, because of the absence of these skills (Mahmoud \& Mohammed, 2014).

Life skills development improves mental well-being in orphans and helps them to face the realities of life. By supporting mental, social and behavioural preparedness, life skills development equips orphans to behave in pro-social ways (Birell Weisen and Orley, 1996). Consequently, life skills development can be seen as empowering orphans and thus enabling them to take more responsibility for their actions (Orley, 1996). Abdulaziz's study (2006) proved the effectiveness of a program to develop the family life skills of girls residing in residential institutions. The study dealt with the following skills: the skill of taking responsibility, decision-making, flexibility and adaptability. Mohamed's study (2014) proved the effectiveness of a drama program to develop some of the life skills for 
orphaned children in social welfare institutions. The study dealt with the skill of communication, safety and security. Mohammed's study (2017) used the task centered model in group work method to develop life skills for orphaned children. The study also sought to develop the skills of responsibility, participation, and expression of feelings.

Social work in the care of orphans is practiced in many governmental and private social institutions. It aims to achieve the proper social adaptation of orphans within their community, inside and outside the institution. It also aims to develop an orphan's personality through integration into society, developing his abilities, discovering his talents and supporting his relations with his relatives.

Social work depends on many professional practice models in dealing with different clients, including the life model (Serouji, \& Abu El-Nasr, 2008).

The life model depends on the ecological perspective which focuses on the relationship between man and his environment, and the problems that the client faces in the life (Hapeep, 2009, p.122). This model is thus consistent with many social work theories and approaches that emphasize that the environment negatively or positively affects the safety of individuals. Individuals could also affect the environment in ways that increase or decrease its ability to facilitate life (Kondrat, 2013, p.350).

Gitterman, \& Germain, (2008) identified the main objectives of the life model: a) Strengthening individuals and their internal motivation towards continuous growth and towards realizing their potential. b) Helping the client to improve his/her social performance and achieve an appropriate level of psychological and social compatibility. c) Achieving an environmental standard suitable for individuals, families, small groups and communities. d) Changing environments to meet and satisfy needs and achieve maximum wellbeing (p.2).

The researcher considers that the life model is one of the most suitable models for dealing with orphans and developing their life skills, considering that what has happened to them is a change in life that has required a change in personality. This model also focuses on releasing the abilities and skills available to orphans which are compatible with their society and alleviate the problems they face. Some studies have proven the effectiveness of the life model in the professional practice of social work. Amin's study (2011) demonstrated the effectiveness of the professional intervention 
program using the life model in social casework in the development of methods of coping with the pressures of life (behavioral, cognitive, emotional, spiritual) for married university students. Mu'ayli's study (2014) developed a conceptual framework for the professional practice of group work in the light of the life model to help girls housed in care institutions to accept their social reality. Mohammed's study (2014) confirmed the effectiveness of professional intervention using the life model in achieving the social compatibility of working children.

In light of the above, the problem of lacking life skills for orphans has been demonstrated by some theoretical writings and previous studies.

The problem of the study can be stated as follows: investigating the effectiveness of the life model of social work in developing life skills for orphans.

Study Objectives: The main objective of this study is to identify the effectiveness of the life model of social work in developing life skills for orphans.

Study Hypotheses: The following hypotheses were formulated:

1. There is a significant difference between the mean degrees of the experimental and control groups after the application of the professional intervention program, when using the life model in social work on the scale of life skills for orphans, in favor of the experimental group.

2. There is a significant difference between the mean degrees of the experimental group before and after the application of the professional intervention program, when using the life model in social work on the scale of life skills for orphans, in favor of the post-test.

3. There is no significant difference between the mean degrees of the control group in the pre-test and post-test on the scale of life skills for orphans.

The researcher defined the operational concepts of the study as follows:

Orphan: Operationally defined as a child who is deprived of family care because of the death of one or both parents, is a resident of the institution for the care of boys and is not less than 12 years of age and not more than 17 years of age and has a low degree on the life skills scale. 
Life skills for orphans: A set of human skills that orphans learn through a professional intervention program based on the strategies and techniques of a life model in social work, which help them to live independently and adapt within the community, and includes the skills of problem-solving and decision-making; communication and dealing with others; and managing emotions and coping with stress.

\section{Methodology}

The current research is an experimental study that aims to identify the effectiveness of a life model of social work in the development of life skills for orphans. The study followed an experimental approach based on two groups; an experimental group and a control group. Following data collection, appropriate statistical analysis was carried out.

Sample: The study population included orphans from the Ahmed Jabra Foundation for Boys Welfare in Qena. A sample consisting of 30 orphans was selected randomly, and divided into two groups; one experimental and one control group. Each group consisted of fifteen members. The sample was selected according to the following criteria: written approvals from the study participants, and cooperation with the researcher in implementing the study.

The study found no statistically significant differences among the mean scores of the experimental and control groups on the scale of life skills for orphans in pre-testing. The arithmetic mean of the experimental group was (52.93), with a standard deviation of (3.327). The arithmetic mean of the control group was (52.67), with a standard deviation of (3.177). The value of "Mann-Whitney U" test was nonstatistically significant $U=(106)$, which shows consistency between the experimental and control groups. The study was implemented from $1 / 12 / 2018$ to $1 / 3 / 2019$. The professional intervention program was implemented over a period of three months through weekly sessions, and the study tools were represented in the Life Skills Scale for Orphans.

Tools: The life skills scale for orphans has three components as shown: the skills problem-solving and decision-making which contains (10) items, the skills of communication and dealing with others which contains (11) items, the skills of managing emotions and coping with stress which contains (10) items. In total the life skills scale for orphans contains (31) items. The scale used the triple Likert method, and included the following options: agree $=3$; neutral $=2$; and disagree $=1$. 


\section{Reliability and Validity of the Scale:}

- Face validity: the researcher presented the scale to (12) reviewers, who are specialists in social work and experts in life skills for orphans. They examined the life skills scale for orphans and expressed their opinions on the stability of the scale items that contribute to the aims of the study. The researcher made all the modifications suggested. Approval was given to $80 \%$ of the items.

- Internal Consistency: the scale was applied in its final form to a sample of (5) orphans. The correlation coefficients were calculated by the index to which they belong. The correlation coefficients between the scale dimensions and the scale as a whole were calculated, the following table illustrates this.

Table (1): The correlation coefficients between every item and the dimension to which it belongs

\begin{tabular}{||l||c||}
\hline \multicolumn{1}{|c||}{ Dimensions } & Pearson Correlation \\
\hline \hline Problem-solving and decision-making & $0.813^{* *}$ \\
\hline \hline Communication and dealing with others & $0.843 * *$ \\
\hline \hline Managing emotions and coping with stress & $0.820^{* *}$ \\
\hline \hline Total & $0.820 * *$ \\
\hline \hline
\end{tabular}

Table (1) shows that all the life skills scale dimensions for orphans relate to each other and correlate with the whole degree of the scale, with a statistically significant correlation at a significant level of (0.01). They achieve a good level of confidence in the tool and reliability of the results, so the researcher can rely on it in the current study.

\section{Scale Reliability:}

Table (2): Results of the reliability of the life skills scale for orphans using the Spearman Brown correction and the Alpha Cronbach Coefficient. $\mathrm{N}=5$

\begin{tabular}{||c||c||c||}
\hline Dimensions & $\begin{array}{c}\text { The Spearman- } \\
\text { Brown }\end{array}$ & $\begin{array}{c}\text { Alpha Cronbach } \\
\text { Coefficient }\end{array}$ \\
\hline \hline Life skills & $0.832^{* *}$ & $0.890^{* *}$ \\
\hline
\end{tabular}

The table (2) shows that most of the coefficients of the scale have a high degree of reliability. This is an indication of the scale's validity and applicability. 


\section{The Professional Intervention Program Using a Life Model of Social Work}

The professional intervention program was developed in view of the principles, objectives, strategies, techniques and steps of a life model of social work, and it is linked to the aims of the current study.

1) The objectives of the Intervention Program: The main objective of the intervention program can be determined as developing life skills for orphans through the use of a life model of social work. The following sub-objectives: (a) developing problem-solving and decision-making skills for orphans, (b) developing communication and interaction skills for orphans, and (c) developing the skills of managing emotions and coping with stress for orphans.

2) The life model strategies used in the program: empowerment, rebalancing and building hope, persuasion, clarification, cooperation, building relationships, emotional adjustment.

3) The life model techniques used in the program: role play, group discussion, clarification, explanation, persuasion, exploration, selfdirection, cooperation, modeling.

4) The professional roles used in the intervention program: behavior changer, coordinator, enabler, assistant, advocate, planner, educator, evaluator.

5) The professional skills used in the intervention program: building professional relationships, decision-making, problem solving, listening, interviewing, facilitating dialogue and discussion, communication, persuasion, observation.

\section{Phases of professional intervention in the life model:}

The life model focuses initially on clarification, contracting and evaluation so that it becomes clear to the social worker why he is helping and how to do it. Professional intervention using the life model is done according to the following Phases:

A. Initial Phase: Getting started. The beginning of work with orphans where individual and group meetings and interviews were held. Also, orphans are contracted about the next steps to be taken.

B. Maturity Phase: At this stage, the problem was identified and formulated, strengths and weaknesses were identified, methods for dealing with orphans were identified and assessed on an individual basis for each orphan and at group level, the definition of the study objectives.

C. Intervention Phase: Working toward goals. The implementation and achievement of the objectives developed in the previous stage. These were developed as tasks performed by the practitioner and 
orphans and included the following steps: setting priorities, setting goals and objectives, knowledge of sources of power.

D. Ending Phase: Bringing the shared work. At this stage the process of bringing about change has been completed and the objectives have been achieved. Bringing the study to a close was set out with the orphans and the work team.

\section{Results of the Study:}

(1) Results of the third hypothesis of the study:

Table (3) shows the differences between the mean degrees of the experimental and control groups after the application of the professional intervention program, using the Man Wuatny test.

\begin{tabular}{|c|c|c|c|c|c|c|}
\hline \multirow{3}{*}{ Dimensions } & \multirow{2}{*}{\multicolumn{2}{|c|}{$\begin{array}{c}\text { Experimental } \\
\mathrm{N}=15\end{array}$}} & \multirow{2}{*}{\multicolumn{2}{|c|}{$\begin{array}{l}\text { Control } \\
\mathrm{N}=15 \\
\end{array}$}} & \multirow{3}{*}{$\begin{array}{l}\text { Ratio } \\
\text { Ratio }\end{array}$} & \multirow{3}{*}{$\begin{array}{c}\text { Sig } \\
\text { (p.value) }\end{array}$} \\
\hline & & & & & & \\
\hline & $\overline{\bar{M}}$ & "S.D & $\mathbf{M}$ & S.D & & \\
\hline $\begin{array}{ll}\begin{array}{l}\text { Problem-solving } \\
\text { decision-making }\end{array} & \text { and } \\
\end{array}$ & 25.33 & 2.127 & 13.20 & 1.521 & 4.689 & 0.01 \\
\hline $\begin{array}{ll}\text { Communication } & \text { and } \\
\text { dealing with others }\end{array}$ & 29.60 & .828 & 13.67 & 1.175 & 4.729 & 0.01 \\
\hline $\begin{array}{l}\text { Managing emotions and } \\
\text { coping with stress }\end{array}$ & 26.13 & 1.457 & 12.60 & 1.595 & 4.692 & 0.01 \\
\hline Total & 107.73 & 2.251 & 52.67 & 3.177 & 4.684 & 0.01 \\
\hline
\end{tabular}

*U.ratio = Man Wuatny. Significant $\mathrm{U}<51$ at the level of 0.01 .

The results of the previous table indicate that there are significant differences between the mean degrees of the experimental and control groups after the application of the professional intervention program on the life skills scale for orphans, by its four dimensions (problem-solving and decision-making; creative thinking and critical thinking; communication and dealing with others; and managing emotions and coping with stress), in favor of the experimental group, where the value of "Man Wuatny" test $U=(4.684)$ and is statistically significant at $(0.01)$. These differences were higher in the experimental group, where the mean of the control group was (52.67), while the mean of the experimental group was (107.73). This means that the professional intervention program of the life model of social work has led to developing life skills for the experimental group, thus proving the validity of the third hypothesis of the study "There is a significant difference between the mean degrees of the experimental and control groups after the application of the professional intervention program, when using the a life model of social work on the scale of life skills for orphans, in favor of the experimental group." 


\section{(2) Results of the First Hypothesis of the Study:}

Table (4) shows the differences between the mean scores of the experimental group before and after the application of the professional intervention program, using the Wilcoxon -Test.

\begin{tabular}{|c|c|c|c|c|c|c|}
\hline \multirow{3}{*}{ Dimensions } & \multirow{2}{*}{\multicolumn{2}{|c|}{$\begin{array}{c}\begin{array}{c}\text { Before } \\
\text { intervention }\end{array} \\
\mathrm{N}=15\end{array}$}} & \multirow{2}{*}{\multicolumn{2}{|c|}{$\begin{array}{c}\begin{array}{c}\text { After } \\
\text { intervention }\end{array} \\
\mathrm{N}=15\end{array}$}} & \multirow{3}{*}{$\begin{array}{l}* \mathrm{Z} . \\
\text { ratio }\end{array}$} & \multirow{3}{*}{$\begin{array}{c}\text { Sig } \\
\text { (p.value) }\end{array}$} \\
\hline & & & & & & \\
\hline & $\bar{M}$ & S.D & $\bar{M}$ & S.D & & \\
\hline $\begin{array}{l}\text { Problem-solving } \\
\text { and decision- } \\
\text { making }\end{array}$ & 13.07 & 1.534 & 25.33 & 2.127 & 3.426 & 0.01 \\
\hline $\begin{array}{l}\text { Communication } \\
\text { and dealing with } \\
\text { others }\end{array}$ & 13.87 & 1.187 & 29.60 & .828 & 3.438 & 0.01 \\
\hline $\begin{array}{l}\text { Managing } \\
\text { emotions and } \\
\text { coping with stress }\end{array}$ & 13.13 & 1.552 & 26.13 & 1.457 & 3.424 & 0.01 \\
\hline Total & (52.93 & 3.327 & 107.73 & 2.251 & 3.41 & 0.01 \\
\hline
\end{tabular}

Z. ratio $=$ Wilcoxon. Significant $Z<15$ at the level of 0.01 .

The results of the previous table show that there were statistically significant differences between the pre- and post-test of the experimental group on the life skills scale for orphans, by its four dimensions (problem-solving and decision-making; creative thinking and critical thinking; communication and dealing with others; and managing emotions and coping with stress), where the value of "Wilcoxon" test $Z=(3.41)$ and was statistically significant at (0.01). These differences were higher in the post-measure, where the mean of the pre-measure was (52.93), while the mean of post-measure was (107.73). This means that the professional intervention program of the life model of social work has led to developing life skills for orphans, thus proving the validity of the first hypothesis of the study "There is a significant difference between the mean degrees of the experimental group before and after the application of the professional intervention program, when using the life model of social work on the scale of life skills for orphans, in favor of the post-test." 


\section{(3) Results of the second hypothesis of the study:}

Table (5) shows the differences between the mean degrees of the control group in the before and after measurement, using the Wilcoxon Test

\begin{tabular}{|c|c|c|c|c|c|c|}
\hline \multirow{3}{*}{ Dimensions } & \multirow{2}{*}{\multicolumn{2}{|c|}{$\begin{array}{c}\begin{array}{c}\text { Before } \\
\text { intervention }\end{array} \\
\mathrm{N}=15\end{array}$}} & \multirow{2}{*}{\multicolumn{2}{|c|}{$\begin{array}{c}\begin{array}{c}\text { After } \\
\text { intervention }\end{array} \\
\mathrm{N}=15 \\
\end{array}$}} & \multirow[t]{3}{*}{$\begin{array}{l}* \mathrm{Z} . \\
\text { ratio }\end{array}$} & \multirow[t]{3}{*}{$\begin{array}{c}\text { Sig } \\
\text { (p.value) }\end{array}$} \\
\hline & & & & & & \\
\hline & $\bar{M}$ & S.D & $\bar{M}$ & S.D & & \\
\hline $\begin{array}{l}\text { Problem-solving } \\
\text { and decision- } \\
\text { making }\end{array}$ & 13.47 & 1.552 & 13.20 & 1.521 & 223 & 0.214 \\
\hline $\begin{array}{l}\text { Communication } \\
\text { and dealing with } \\
\text { others }\end{array}$ & 13.60 & 1.121 & 13.67 & 1.175 & 229 & 0.317 \\
\hline $\begin{array}{l}\text { Managing } \\
\text { emotions and } \\
\text { coping with stress }\end{array}$ & 13.20 & 1.568 & 12.60 & 1.595 & 206 & 0.024 \\
\hline Total & $\begin{array}{l}53.67 \\
\end{array}$ & 3.200 & $\bar{~} 52.67$ & 3.177 & 212 & 0.039 \\
\hline
\end{tabular}

*Z. ratio $=$ Wilcoxon. Significant $\mathrm{Z}<\mathbf{1 5}$ at the level of 0.01 .

The results of the previous table show there are no significant differences between the mean degrees of the control group in the pretest and post-test on the life skills scale for orphans, by its four dimensions (problem-solving and decision-making; creative thinking and critical thinking; communication and dealing with others; and managing emotions and coping with stress), where the value of "Wilcoxon" test $Z=(212)$ and is not statistically significant at (0.01), thus proving the validity of the second hypothesis of the study "There is no significant difference between the mean degrees of the control group in the pre-test and post-test on the scale of life skills for orphans." 
Table (6) shows Blake's modified gain ratio in developing life skills for orphans.

\begin{tabular}{|c|c|c|c|c|}
\hline Dimensions & $\begin{array}{l}\text { Mean Before } \\
\text { measurement }\end{array}$ & $\begin{array}{l}\text { Mean After } \\
\text { measurement }\end{array}$ & $\begin{array}{c}\text { Degree } \\
\text { of } \\
\text { grandeur }\end{array}$ & $\begin{array}{l}\text { modified } \\
\text { gain ratio } \\
\text { (blake) } \\
\end{array}$ \\
\hline $\begin{array}{l}\text { Problem-solving } \\
\text { and decision- } \\
\text { making }\end{array}$ & 13.07 & 25.33 & 30 & 1.42 \\
\hline $\begin{array}{l}\text { Communication } \\
\text { and dealing with } \\
\text { others }\end{array}$ & 13.87 & 29.60 & 33 & 1.49 \\
\hline $\begin{array}{l}\text { Managing } \\
\text { emotions and } \\
\text { coping with stress }\end{array}$ & 13.13 & 26.13 & 30 & 1.43 \\
\hline Total & 52.93 & 107.73 & 123 & 1.50 \\
\hline
\end{tabular}

The results of the previous table show Blake's modified gain ratio in developing life skills for orphans. Its dimensions are between (1.42 and 1.50) which is higher than the rate proposed by "Black" to judge the effectiveness of the program (1.2). The professional intervention program, using the life model, was effective and contributed to developing life skills for orphans.

Table (7) shows the value of Eta Squared ( $\eta 2)$ and the practical significance of the difference between the mean degrees of the experimental group before and after the application of the professional intervention program

\begin{tabular}{||c||c||c||c||}
\hline Variables & Eta & Eta Squared & Sig \\
\hline \hline Developing life skills for orphans & 0.891 & 0.883 & 0.892 \\
\hline
\end{tabular}

The results of the previous table indicate that the value of Eta Squared $(\eta 2)$ was 0.883 , which means that the percentage of total variance in degrees of the sample, due to the impact of the professional intervention program using the life model, applied to the experimental group, is 0.891 , which means that the program prepared by the researcher has developed the life skills for orphans by $89.2 \%$.

\section{Discussion:}

This study aimed to identify the effectiveness of the life model of social work in developing life skills for orphans, using strategies and techniques of life model. They will be discussed in view of the study results. 
In general, the study found that the positive impact of the vocational intervention program was demonstrated by using the life model in developing life skills for orphans, that is by developing skills of problem-solving and decision-making, communication and dealing with others, and managing emotions and coping with stress.

The success of the professional intervention program is due to the researcher's use of strategies and techniques of the life model, including: strategies of empowerment, rebalancing and building hope, persuasion, clarification, cooperation, building relationships, and emotional adjustment. Techniques of role-play, group discussion, selfdirection, cooperation, and modeling were used, and the program benefited from the resources and possibilities of the institution, and experts in the field of orphans.

The results of the study showed the effectiveness of the professional intervention program, using the life model of social work in developing problem-solving and decision-making skills for orphans. This is manifested in the ability of the orphan to feel the existence of a problem, to determine the quality of the problem that has occurred, or is likely to occur later, so he can avoid what the causes it (Mohammed, 2011). The orphan can identify all possible alternatives, analyze them using appropriate criteria such as their benefits and efforts, taking into account the assessment (Abdulaziz, 2006) and reassessment of alternatives in the light of the risks that may arise from them, then choose the best alternative and implement it (Abdelmaty, 2014).

The results of the study showed the effectiveness of the professional intervention program, using the life model of social work, in developing communication skills and the skills for dealing with others. This is manifested in the ability of the orphan to communicate with others through writing, body language, or symbols (Rabie, 2018). The ability to receive messages from others and to know what they feel or think during the dialogue and the ability to identify the information required to be delivered in the message and the development of communication tools to make a successful connection (Elbassati, 2012) in the practice of various activities (Ahmed, 2009).

Additionally, the results of the study showed the effectiveness of the professional intervention program, using the life model of social work, in developing the skills of managing emotions and coping with stress for orphans. This is manifested in the ability of the orphan to calm himself, to get rid of the dominant anxiety, depression, despair 
and rapid agitation (Mohammed, 2017) to act productively in disturbing situations and to calm oneself quickly when angry, and to think about negative emotions carefully without sadness, and have the ability to relax in stressful situations (Mahmoud, 2011).

The results of this study agree with the results of some previous studies aimed at testing the effectiveness of professional intervention using the life model with the different categories. These studies include: Elbassati's study (2012) that proved the effectiveness the life model from the perspective of the generalist practice of social work and the development of a female breadwinner's life skills. And the results of El-Mayzr's study (2008) which presented a proposal to practice the life model in achieving social support for mothers of orphans. Awad's (2008) study showed that the life model has lessened the pressure on prisoners' wives. Also, Idris's study (2015) reached to determine the perspective of a life model for patients with chronic kidney failure by social support. Adam's study (2018) used the life model from the perspective of generalist practice in social work to achieve social adjustment for the elderly.

Finally, it can be concluded that this study's results differ from the results of previous studies. The current study has verified the effectiveness of the life model of social work in developing life skills for orphans, while previous studies used the life model in professional practice with different clients.

\section{Study Limitations:}

- Difficulty of administrative procedures to accept the application of the study in the institution.

- Lack of knowledge, skills and experience of service providers for orphans.

- Lack of commitment of some orphans to implementing required activities associated with the intervention program. 


\section{References:}

Abdulaziz, M. A. (2006). A program to develop the family life skills of girls residing in residential institutions. master thesis, Cairo University, Institute of Research and Educational Studies.

Abdelmaty, H. I. (2014). Effectiveness of a counseling program to develop some life skills in a sample of deaf children. Journal of reading and knowledge, Egyptian Society for Reading and Knowledge, N.150, pp. $153-165$

Abo-Elfotouh, R. (2004). Using group worker for Collective Interaction Techniques in Satisfying Social Needs. $\mathrm{PhD}$ thesis, Helwan University, Faculty of Social Work.

Adam, S. A. (2018). Practice the life model from the perspective of generalist practice in social work to achieve social adjustment for the elderly. Journal of Social Work, Egyptian Association of Social Workers, N.59, V.1.

Ahmed, A. (2009). Group work practice and the providing of illiterate girls with life skills. Journal of Studies in Social Work and Human Sciences, Helwan University, Faculty of Social Work, N.26, V.3.

Al Mu'aily, N. M. (2014). The life model in group work to help girls housed in entertainment institutions to accept their social reality. Journal of Studies in Social Work and Human Sciences, Helwan University, Faculty of Social Work, N.36, V.1.

Al-Qazzaz, M. S. (2005). Parental Education in Early Childhood, Cairo, Farah Publishing House.

Amin, H. A. (2011). The relationship between practicing the model of life in the social casework and developing the methods of coping with the life pressures of the married university student. Journal of Studies in Social Work and Human Sciences, Helwan University, Faculty of Social Work, N.30, V.7.

Awad, S. A. (2008). The effectiveness of the life model in alleviating the pressures of prisoners' wives. Journal of Studies in Social Work and Human Sciences, Helwan University, Faculty of Social Work, N.25, V.2.

Birell, W. R. \& Orley, J. (1996). Life skills Education: Planning for research as an integral part of life skills education development, implementation and maintenance. Geneva, WHO, Programme on Mental Health.

Elbassati, E. H. (2012). Professional intervention in the life model from the perspective of the generalist practice of social work and the developing of women breadwinner's life skills. the 25th scientific conference of social work, V.8. Helwan University, Faculty of Social Work. 
El-mayzr, H. (2008). Imagine a proposal to practice the life model in achieving social support for mothers of orphans. Journal of Studies in Social Work and Human Sciences, Helwan University, Faculty of Social Work, N.25, V.1

Hapeep, G. (1995). Psychological and social risks to the children of residential institutions and the role of social work in facing them. the 8th scientific conference of social work, Helwan University, Faculty of Social Work.

Hapeep, G. (2009). Generalist practice a modern perspective in social work. Alexandria: Modern University Office.

Ibrahim, S. S. (2006). Development of some life skills and the trend towards science in the students of the preparatory stage using the sources of community learning. Master Thesis, Ain Shams University, Faculty of Education.

Idris, J. M. (2015). A proposal perspective for practice a model of life to achieve social support for patients with chronic kidney failure. AlAmarat: Journal of Social Affairs, N.128, V. 32.

Jalal, S. (2013). Childhood and adolescence. Alexandria: Modern Knowledge Office.

Johnson, A. \& Grose, V. (1994). The orphaned and institutionalized children of Romania. journal of Emotional and Behavioral Problems, V.2, N.2.

Khalil, A. Z. (1995). The practice of real treatment in the service of the individual and alleviate the psychological and social problems of orphans. the 8th scientific conference of social work, Helwan university, Faculty of Social Work.

Kondrat, M. (2013). Person-in-Environment. Encyclopedia of Social Work, Ed. Retrieved 24 Jan. 2019, from http://oxfordre.com/socialwork/view/10.1093/acrefore/97801999758 39.001.0001/acrefore-9780199975839-e-285.

Mohammed, A. E. (2014). Proved the effectiveness of a drama program to develop some of the life skills of an orphan child in social welfare institutions. $\mathrm{PhD}$ thesis, Mansoura university, faculty of specific education.

Mohammed, A. Z. (2014). The effectiveness of professional intervention using the life model in achieving the social compatibility of working child. Journal of Studies in Social Work and Human Sciences, Helwan university, Faculty of Social Work, N.37, V.3.

Mohammed, H. J. (2011). Role of group work in providing young people with life skills. master thesis, Helwan University, Faculty of Social Work.

Mohammed, H. M. (2017). Using task centered model in group work method to develop life skills for orphan child. $\mathrm{PhD}$ thesis, Alexandria University, Institute of Social Sciences. 


\begin{tabular}{|llc||}
\hline \multicolumn{2}{|l|}{ Egyptian Journal of Social Work (EJSW) } & http://ejsw.journals.ekb.eg \\
Print ISSN: 2356-9204 & Online ISSN: 2356-9212 & Vol 8, Issue 1, June 2019 \\
\hline \hline
\end{tabular}

Mahmoud, L. M. \& Mohammed, D. I. (2014). Life Skills of University Students. Diyala Journal, Diyala University, V.1.

Mahmoud, M. S. (2011). A proposed program for professional intervention with orphans children groups and developing them. master thesis, Helwan University, Faculty of Social Work.

Serouji, T. \& Abu El-Nasr, M. M. (2008). Models of modern practice in the profession of social work. Journal of studies in the social work and humanities, Helwan university, Faculty Of Social Work. N.25, V.1.

Rabie, H. M. (2018). Contributions of the community group work in developing life skills for secondary technical education students. master thesis, Fayoum University, Faculty of Social Work.

UNICEF. (2001). Definition of orphans. Available from UNICEF, or at https://www.unicef.org/media/orphans.

UNICEF. (2003). Definition of Life skills, Available from UNICEF, or at https://www.unicef.org/lifeskills/index_7308.html

World Health Organization [WHO]. (2001). Skills for health. WHO information series on school health. https://www.who.int/school_youth_health/media/en/sch_skills4healt h_03.pdf

World Health Organization [WHO]. (2003). Life skills education in schools. Available from $\mathrm{WHO} / \mathrm{mnh} / \mathrm{psf} / 93.7 \mathrm{a} . \mathrm{rev} .2$. 